\title{
論点・風工学
}

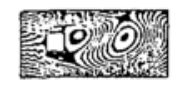

\section{自己回帰式を用いたスペクトル解析法における次数について On the order of autoregressive model for spectral estimation}

\section{1.はじめに}

平坦な地域上での大気乱流のスペクトルは中立成層 で定常状態の時には白色雑音をローパスフィルターに 通して得られるような変動のスペクトルの形になる場 合が多い。このようなスペクトルを持つ変動を筆者の 同僚の一人が「ピンクノイズ」と呼んだ事がある。白 色から高周波の青色をフィルターで取り除いたので, 残りはピンク色になるというのである。このピンク色 をした変動のスペクトルをMaximum Entropy Method (MEM) で求める際の実際的な手続き上の問題点に関 して筆者は以前に本誌の第 35 号において「MEMに よるスペクトル解析について」と題して一文1 を書い た。ここでは同様の変動を自己回帰式を利用したスぺ クトル解析法によって解析する際の具体的な問題につ いて述べてみたい。

\section{MEMとAR法}

筆者はかつてF P Eを用いてMEMにより強風のデ 一タを解析したことがある。そのとき得られたカーブ はいずれもカルマンタイプのスペクトルでよく近似で きた。積分スケールとピーク周波数もカルマンタイプ のスペクトルのときに互いに成り立つ関係を見事に満 たした。その結果を日本気象学会1983年秋期大会で報 告"2) したものの, 過去の経験からしてどこか引っかか るものも感じていた。得られた結果が本当に自然の実 際の姿を反映したものになっているのだろうかー- という懸念が消えなかった。MEMでは得られたスぺ クトルの信頼度を検定する方法はないとされており，
しかたなく，与えられたスペクトルをもつ変動をシミ ュレートして, それをMEMで解析して, 正しく解析 できるかをチェックした。1988年のこの覧での報告1) はこのチェックの結果にもとずいていた。筆者の奬念 は的中し，上記の方法で得られたスペクトルは事実を 正しく反映したものでなかった。F P Eを用いて次数 を決め, MEMによって得たスペクトルはカルマンタ イプ以外のスペクトルをもつ「ピンクノイズ」にたい しても，カルマンタイプのスペクトルで近似できるも のとなった。やむなく日本気象学会1984年春期大会で は，1983年秋期大会で示した結果は事実を正しく反映 したものではなく，解析法の適用の間違いによって導 き出された歪められた結果であることを報告3) しなけ ればならなかった。

MEMについてはその利点とともに, 問題点も指摘 されている。MEMの優れた点は（a）データの長さ に比べて, 長周期の変動のスペクトルが解析可能であ ること, （b）分解能が優れ，線スペクトルに近いよ うなシャープなスペクトルを求めることができること などが挙げられている。他方, 欠点として, (a ) そ の次数を決める客観的な方法がないこと, (b) 求め られたスペクトルの信頼性を評価する方法が見つかっ ていないことなどが挙げられている。この後者の欠点 とも関連して, 前者の欠点がより一層重い意味を持つ ことがある。次数を決める客観的な方法がなく，なん らかの方法で次数を決定して, スペクトルを求めるこ とになる。しかし，その結果の信頼性をチェックする ことができないので，結果は当然一人歩きを始めるこ

* 日本大学生産工学部, 助教授

Associate Professor, Industrial Technology, Nihon University (原稿受理：平成 2 年10月16日) 
とになる。次数を決定することが決定的な意味を持っ てしまうことになる。次数の決定を誤ると, 誤った結 果が一人歩きを始める。筆者の苦い経験はこのことを 物語っている。

MEMr A R 法（自己回帰式の係数を自己相関関数 を用いて決定し, その係数からスペクトルを求める方 法）は全く異なった発想で作り出されたものであるが, 両者は親類関係にあることがわかっている。日野の著 書4)には「MEMによるスペクトル解析は, 確率過程 に自己回㷌式をあてはめることに相等しい」とある。 そしてその結果, MEMによるスペクトル解析におけ る次数の決定に F P E を用いることに根拠が与えられ た。また同時に, 日野の著書4)には「鋭いスペクトル ラインをもつランダム変動では, F P E がはっきりし た極小值を示さないので, (次数を) 全デー夕数の半 分以下で打ち切る必要がある」とあり, F P Eが有効 に作用しない場合のあることも述べられている。鋭い スペクトルラインをもつランダム変動と対極にあるよ うな「ピンクノイズ」の解析ではF P Eが最小になる 次数では逆に小さすぎることは筆者がすでに報告した ことである。そして, ある限定された範囲においてで はあるが, デー夕数の平方根が適切な次数の大きさの おおまかな目安になることとともに, 解析可能な周波 数帯に関して低周波数側に限界のあることも述べた。

\section{FPEによる回帰次数の決定に関して}

日本風工学会誌 No.42の論点・風工学に揭載された 前田 ${ }^{5)}$ の論点に触れてみたい。その結びでは「AR 次数に時系列のデー夕数の平方根を設定したARスペ クトルを見かけることがあるが, 筆者はこのような次 数決定に替成できない。」と述べている。その根拠と して同文のFig. 1 をあげている。同図は自己相関関数 が指数関数になる変動を例にとり, ラグ時間の関数と して, 自己相関関数の基準化標準誤差をデータ長をパ ラメータとして表わしたものである。このグラフと自 己回帰式の次数の決定とどう関係があるのか筆者には 理解できない。前田は「回㷌次数を上げることによっ て, …自己相関関数の推定精度の悪い領域を使 用する可能性があるからである。」と述べている。一 定の長さのデータから自己相関関数を推定すれば大き なラグ時間に対して算定精度が悪くなり, その利用に 際して一定の制約を受けるのは当然であるが, 回㷌次 数を具体的にいくらにするかという問題と結び付ける
には飛躍が大きすぎる。回㷌次数を小さくしたからと いって，風速変動を自己回帰式に当てはめたときに， 例えば，大きなラグ時間の自己相関関数までより精度 良く記述できるという保証はどこにもない。

筆者は回帰次数の大きさをデー夕数の平方根と関係 づけたものの一人であるが,これを誰かに押しつける 気持ちは毛頭ないし, これが唯一の手段だとも全く思 わない。もっと一般化されエレガントで, かつ自己相 関関数やスペクトルを正しく求めることのできる方法 があれば, 発表してもらいたいとも考える。しかし, スペクトルの形を低周波領域までなるべく現実のまま に求めることを考えると赤池のF P E を用いる方法で はうまくいかなかった。これはすでに述べたとおりで ある。前田は結びで「・・・安全性など問題点がな いわけではないが, ARモデルを用いる限りにおいて は筆者は赤池の F P E 基準を用いた次数決定を使用し ている」と述べている。結びでこのような主張をする けれども，それ以前の本文ではF P E を用いることの 有効性についてはまったく触れられていない。よく読 めばむしろ逆の結果と理解できる面もある。理論モデ ルの自己相関関数から A R 係数を決め, その值からパ ワースペクトルを求めている。その結果とモデルのパ ワースペクトルを比較して，「視察で良く一致すると いえるのはDryden型 $\mathrm{v}$ 成分で30次以上，Karman型 $\mathrm{u}$ 成 分で10次以上, Karman型 $\mathrm{v}$ 成分では40 50次以上であ った。」と述べている。この結果は無次元の時間間隔 $\Delta \tau$ が 0.1 の場合のものである。 $\Delta \tau$ が0.05の場合 の次数の大きさは示されていないが, スペクトルが低 周波領域までよく一致するために必要な次数はさらに 大きくなったものと推測される。F P E基準で次数を 決めたとき, 大気乱流の風速変動の場合には筆者の過 去の経験からはカルマンタイプの風速変動でない場合 も含めて, ほとんどの場合次数は10以下であったし, また前田等の論文 ${ }^{6)}$ でも， 2 次元の時系列の場合では あるが, $\Delta \tau か ゙ 0.02$ 前後のデータの場合に, その值は 4〜7であったと述べられている。筆者の過去の経験 では, 前田によるKarman型 $\mathrm{u}$ 成分のスペクトルを持つ 変動はA R 法の比較的小さい次数で解析のできる変動 であるが, この変動でもよく一致しているといえるに は10以上の次数が必要であるというのが前田の結論で ある。その一方で実際のデー夕解析ではF P E 基準で 決めた次数は10以下の小さい值であった。まして, こ れ以外のタイプの変動では目視でよく一致するといえ るのはなお大きい次数が必要であることは前田自身の 
結論でもあるし，筆者" の一文における結論も同様で あった。このように本文からはむしろ F P Eを用いる ことが望ましいことではないことが示唆されているに もかかわらず，結びでは逆の主張がなされている。た とえ逆の主張というのが強すぎるとしても，少なくと も「F P E 基準を使用している」ことをバックアップ する根拠はなんら与えられていない。

\section{AR法における次数の検討法について}

前田 ${ }^{5)}$ はDryden型とKarman型のみを取り扱っている が，F P E基準を用いたときに問題になるのはこれら の u成分のタイプ以外のスペクトルを持つ変動を解析 する場合である。自己相関関数が指数関数になる変動 は次数 1 の自己回帰式で表現できるものであるし, 犬 気乱流の研究によく現われるカルマンタイプ以外のス ペクトルを持つ変動の場合でも F P E 基準で解析した ときには, 次数は多くの場合に10程度以下となり, そ の低い次数を用いて得られるスペクトルは本来のスペ クトルとは違って, 高周波領域を除き全体としてカル マンタイプに近いものになってしまうというのが筆者 の得た結果であった。したがって, カルマンタイブ以 外の変動について議論してこそF P E 基準を用いるこ との適否が議論できる。ここで以下に述べる方法によ って, 目視でよく一致するといえる次数は他のタイプ のスペクトルの場合ではどの程度の大きさになるかを 検討してみる。

筆者7) は以前シミュレートされた多次元風速変動の 精度と用いた回帰式の次数の大きさとの関係を検討し たことがあるが，その際に用いた手法を一次元の風速 変動の場合に焼き直して利用することにする。つまり， まず最初に, 解析対象の変動のパワースペクトルの值 を離散化して，それを Blackman-Tukey のスペクトル 解析法で用いられているFourier Cosine変換の方法を 利用して, 自己相関関数に変換する（以下の実際の計 算では1000 5000点のスペクトルの値から最大で1000 〜 5000までのlag の相関関数を求めた)。次に,この 自己相関関数から様々な次数の自己回帰式の係数を決 める。さらにその回帰式で表わされる変動のパワース ペクトル (以下ARスペクトルと呼ぶ) を求める。最 後に,このARスペクトルと最初にモデルとしたスペ クトルとを比較して, 両者が目視でよく一致する自己 回帰式の次数の大きさを検討する。

これに対して, 前田5) の場合では, モデルのパワー
スペクトルからWiener-Khintchine の関係式を利用し て解析的に自己相関関数を求め, その値を一定の時間 間隔で離散化して, 自己回臣式の係数の決定に利用し ている。つまり, 逆フーリエ変換をする前にスペクト ルを離散化するか, 逆フーリエ変換をした後で相関関 数を離散化するかという点に笔者の方法と前田の方法 の相違点がある。

この両者の方法の比較なども行いながら, 以下に次 数の大きさに関わる問題を具体的に検討する。

\section{5. パワースペクトルのモデル}

筆者がMEMによるスペクトル解析の検討の際に使 用したパワースペクトル $\mathrm{S}_{0}(\mathrm{n})$ と同じもの, つまり, Fichtl and McVehili) による次の実験式をここでも 用いる。

$$
\frac{\mathrm{S}_{0}(\mathrm{n})}{\sigma^{2}}=\frac{\mathrm{A} / \mathrm{n}_{\mathrm{m}}}{\left(1+1.5\left(\mathrm{n} / \mathrm{n}_{\mathrm{m}}\right)^{k}\right)^{(5 / 3 k)}}
$$

ただし， $\mathrm{n}_{\mathrm{m}}$ は対数パワースペクトルが最大となる周 波数であり, бは変動の標準偏差, Aと k は定数であ って, 次の関係がある。

$$
\mathrm{A}=\frac{1.5^{(1 / \mathrm{k})} \mathrm{k} \Gamma(5 / 3 \mathrm{k})}{\Gamma(2 / 3 \mathrm{k}) \Gamma(1 / \mathrm{k})}
$$

ここで「はガンマ関数を表わす。このスペクトルをも つ変動の積分スケール (時間) Lは次式で与えられる。

$$
\mathrm{L}=\mathrm{A} / 4 \mathrm{n}_{\mathrm{m}}
$$

前田 ${ }^{5)}$ の結果とも比較するために, ここではさらに 上記スペクトルを無次元周波数 ク（周波数 $\mathrm{n}$ を $\mathrm{L}$ で無 次元化したもの）の関数 $S_{1}(\eta)$ に変換する。つまり,

$$
\eta=\mathrm{nL}=\mathrm{An} / 4 \mathrm{n}_{\mathrm{m}}
$$

であるので, 次式が得られる。

$$
\mathrm{S}_{1}(\eta)=\frac{\mathrm{S}_{0}(\mathrm{n})}{\mathrm{L} \sigma^{2}}=\frac{4}{\left(1+1.5(4 \eta / A)^{k}\right)^{(5 / 3 k)}}
$$

ここでクは0からのの範囲をとる。しかし，今回のよ うな時系列の場合には，そのパワースペクトルには時 系列の時間間隔 $\Delta \mathrm{t}$ によって決まるナイキスト周波数 $1 / 2 \Delta \mathrm{t}$ 以上の周波数成分は含まれない。時間 $\mathrm{t}$ を $\mathrm{L}$ 無次元化した $\tau(=\mathrm{t} / \mathrm{L})$ を用いれば $\eta_{\mathrm{n}}=1 / 2 \Delta \tau$ 以 上の周波数成分は含まれない。 $S_{1}(\eta)$ を 0 からめま

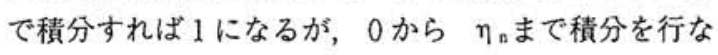
っても1にはならない。そこで式(5)を変形して次式 を用いる。

$S_{2}(\eta)=\frac{4 B}{\left(1+1.5(4 \eta / A)^{k}\right)^{(5 / 3 k)}}$

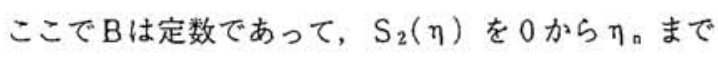


積分した值が 1 となるように決める。このスペクトル をもつ変動の積分スケールは 式(3)の L と若干異なる がスペクトルの無次元化はこのLで行なうこととする。

\section{A R法における次数の検討}

式(1) あるいは式(5) で表わされるスペクトルは, $\mathrm{k}=2$ の場合はカルマンタイプのスペクトルになり, $\mathrm{k}=1$ の場合はPasquill and Butler ${ }^{9)}$ 等によって与 えられたタイプのスペクトルになる。ここでの具体的 検討にはこの 2 種類の $\mathrm{k}$ のスペクトルを用いた。 $\Delta \tau$ については前田 ${ }^{5)}$ と同じ值, つまり，0.1 と0.05に加 えて, $0.02 の$ 場合も検討した。

$\Delta \tau$ が0.1 でkの值が 2 と 1 の場合の結果をFig. 1 とFig. 2 に示す。図の中の実線はモデルとして用いた 式(6) を表わし，＋印はAR法で得たスペクトルを表 わす。以下の図もこの記号はすべて同様である（ただ し, Fig. 5 は除く)。Fig. 1 は前田5) のFig. 5 の上か ら 3 つ目のグラフに対応するものである。両者を比較 してみると, 次数 1 におけるARスペクトルの位置が 互いに違っている。さらに他の次数の高周波数側の端 において互いの結果が異なっており, 前田の結果はモ

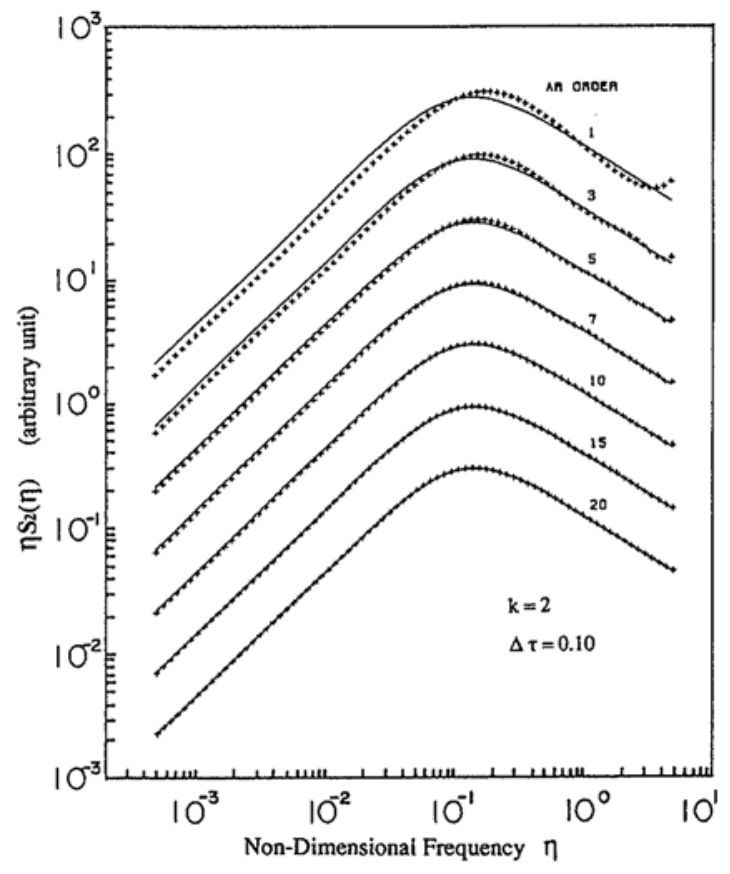

Fig. 1 Model power spectra (solid line) and spectral estimates with finite-order autoregressive models (symbol +++ ). Here $\mathrm{k}=2$ in eq. (6) and the time interval $\Delta \tau=0.10$.
デルのスペクトルより大きな値を示している。この違 い関しては後で述べる。これらの違いを除けば両者の 結果はおおむね一致する。モデルと A R 法で得たスペ クトルを低周波数側までよく一致させるには10以上の 次数が必要である。一方, Fig. 2 の $\mathrm{k}=1$ の場合では モデルとARスペクトルをよく一致させるにはさらに 大きな次数が必要である。次数が小さいときには高周 波数側の一部分のみで一致が見られ, 次数を大きくす るにつれて, 一致する範囲が低周波数側に広がる。こ れはFig. 1 と2 に共通してみられる傾向である。モデ ルのスペクトルのタイプによってその範囲は異なるが, 用いる次数によって解析可能な低周波数側の範囲が限 定される。

つぎに同タイプのスペクトルであっても， $\Delta \tau$ の大 きさによって, モデルのスペクトルと A Rスペクトル を一致させるのに必要な次数は大きく異なる。Fig. 3 とFig. 4 に $\tau$ が0.02の場合の結果を示した。 $\mathrm{k}=2$ で $\Delta \tau=0.10$ 場合には次数10でおおむね一致したが, $\Delta \tau=0.02$ では次数を 50 程度にしなければ一致はみら れない。Fig. 4 の k = 1の場合ではさらに大きな次数 を必要とする。モデルのスペクトルと A Rスペクトル

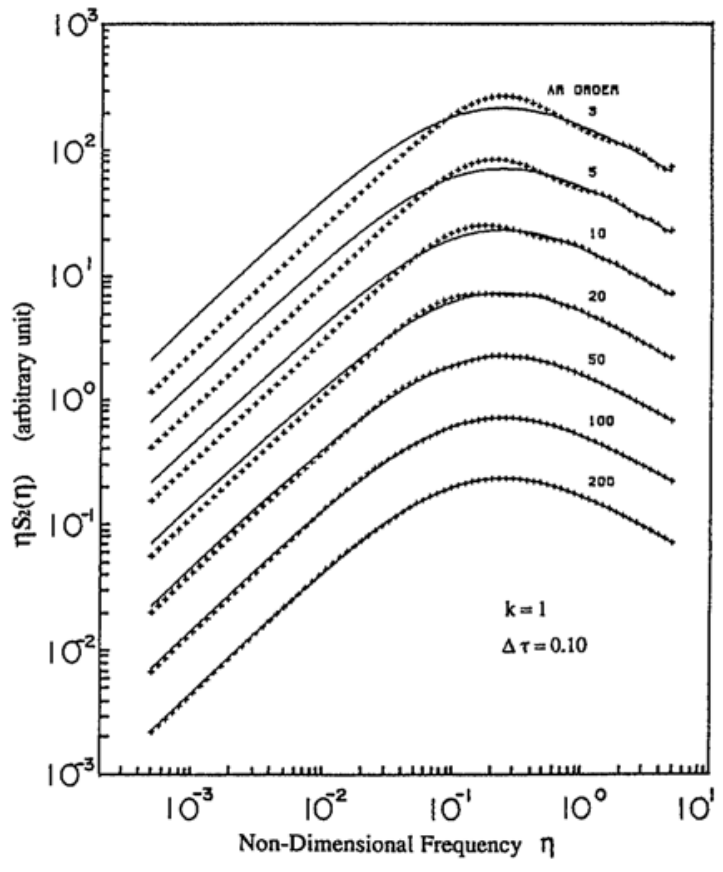

Fig. 2 The same as Fig. 1 except for $k=1$. 


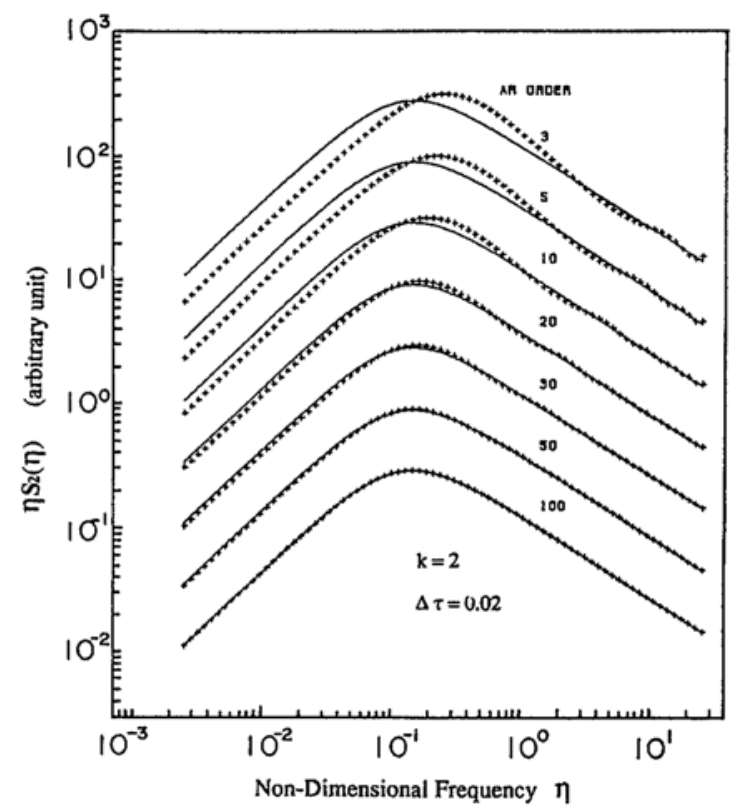

Fig. 3 The same as Fig. 1 except for $\Delta \tau=0.02$.

を一致させるには $\Delta \tau$ が小さくなるにつれてより大き な次数を必要とする。

\section{7. 低次数での解析結果について}

定常な大気乱流に関連した「ピンクノイズ」のAR スペクトルを求める際に, 自己回㷌式の次数を F P E を基準にして決定すると, スペクトルのタイプに関係 なくその次数は10以下になる場合が多い。その定常性 が保証されているシミュレートされた変動ではデー夕 の長さにもほとんど影響されなかった。以上のことは 筆者の経験といくつかの他の人の経験に依存した事柄 であって, 確実に保証された事柄ではない。しかし, いくらか鋭いピークがスペクトルにある場合などを除 いて数十以上になることはなく，ほとんど場合10以下 であるというのが筆者の経験などからの結論である。

そこで低い次数でスペクトルを求めた場合について 検討する。 $\mathrm{k}=1$ に対応するスペクトルを次数 7 で解 析して得られたARスペクトルをFig. 5 に示す。図に は $\Delta \tau$ が0.1,0.05,0.02 の3つの場合をまとめて示し た。図中の実線はカルマンタイプのスペクトルによる 近似曲線である。なお, この近似曲線における周波数 の無次元化は A R スペクトルを求めるときに得られた 積分スケールで行なっている。モデルが $\mathrm{k}=1$ のスペ クトルであるにもかかわらず, $\mathrm{k}=2$ のスペクトルに

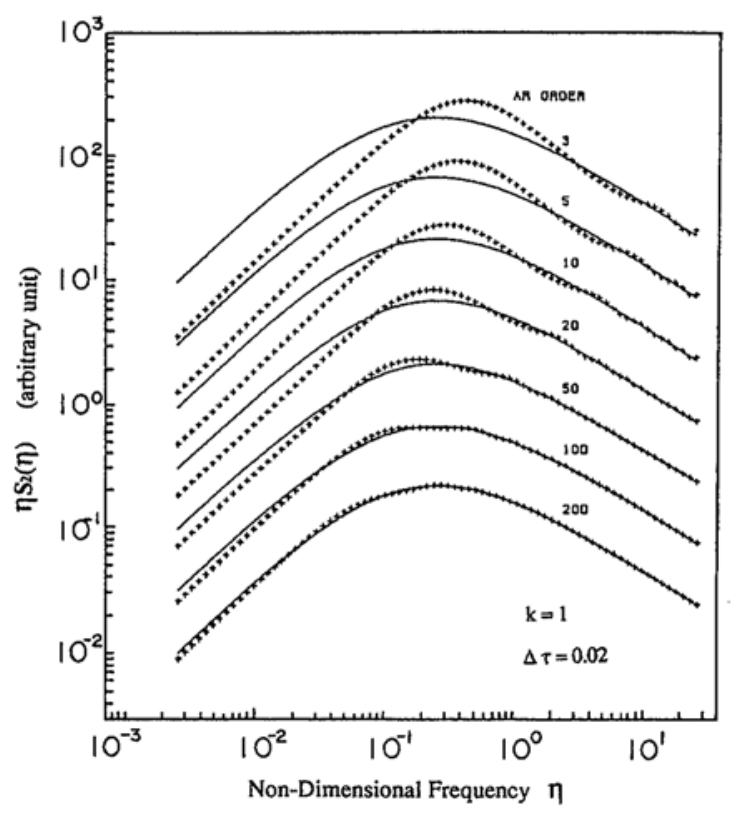

Fig. 4 The same as Fig. 1 except for $\mathrm{k}=1$ and $\Delta \tau=0.02$.

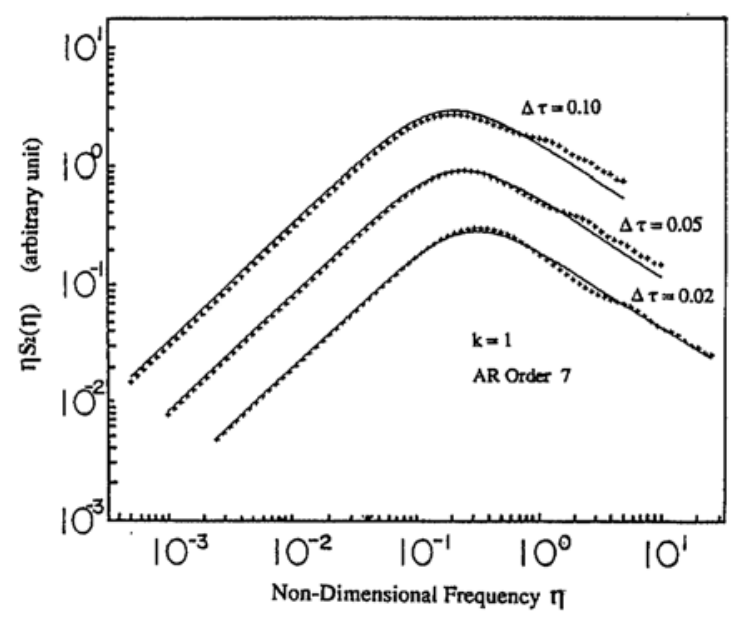

Fig. 5 Estimated power spectra (for eq. (6) with $\mathrm{k}=1$ ) by using autoregressive models of order 7 (symbol +++ ) and curves expressed by eq. (6) with $\mathrm{k}=2$ (solid line) for approximation.

よっておおむね近似ができる。Fig. 2 と 4 では次数が 7 の場合の結果が示されていないが, 次数が 5 と10の 場合の結果から推察してもわかるように, 次数 7 の場 合には $\mathrm{k}=1$ のスペクトルで近似することはできない。 実際の風速デー夕を解析する際にはあらかじめそのス ペクトルの形がわかっているわけでないので，低い次 
数で解析して得られる結果を信用してしまうと, 自然 の姿に関係なく，カルマンタイプのスペクトルという 結果を得ることになりかねない。スペクトルのタイプ によって必要な大きさの次数が F P E 基準で与えられ れば問題はないのであるが,「ピンクノイズ」を取り 扱う際にはそうはならないというのがこれまでの経験 である。この結果は筆者 ${ }^{2)}$ がMEMについて得た結果 とも一致する。

\section{8. 前田の理論モデルとの比較}

筆者の今回のモデルでは相関係数は理論計算による ものでもなく, 精度の高い数值計算に基づくものでも ない。その点で結果にいくぶん簃密さを欠くかもしれ ない。しかし, 次数を十分に大きくとればモデルのス ペクトルとARスペクトルが十分に一致することから して, 目視で判断する程度の精度は保証されていると 考えられる。一方, 前田 ${ }^{5)}$ の理論モデルでは, 「無次 元周波数が大きくなるに連れて両者（モデルのスペク トルと A Rスペクトル) の差がみられるが，これは離 散時間間隔 $\Delta \tau$ を大きくすると顕著になり, 逆に小さ くすると改善できた」という問題が生じる。この原因 については論じられてはいないが, これは解析的に得 られた相関関数を離散化することによって発生する。 つまり解析的に得られた相関関数は周波数が 0 からめ の範囲の変動に関連した値にもかかわらず, 離散化す ることによってスペクトルからナイキスト周波数（1 $/ 2 \Delta \tau)$ 以上の変動を切り捨てることからくる。高 周波の端の領域におけるスペクトルの不一致はエイリ アジングに相当する効果が現われたものである。その 意味から $\Delta \tau$ が小さくなるとともにスペクトルの不一 致が小さくなるのも当然である。このようにこの現象 は相関関数を離散化することから生じたものであって, A R 法に起因したものではない。つまり，相関関数を 離散化した時点でモデルのスペクトルが当初考えたも のとは異なったものに変化している。筆者による今回 の解析ではモデルのスペクトルにおいてナイキスト周 波数以上のスペクトルを 0 としているので高周波の端 の領域での不一致は発生していない。

このような現象を今回のモデルを用いて再現した結 果を以下に示す。 $\Delta \tau$ を0.005 として式(5) （ $\mathrm{k}=2$ とする) より自己相関関数を計算する。次にその 20 個 毎の值を取り出し, $\Delta \tau$ が0.1 の自己相関関数に変換 する。それを用いて A R スペクトルを計算する。その 結果をFig. 6 に示した。次数 1 における值はFig. 1 に

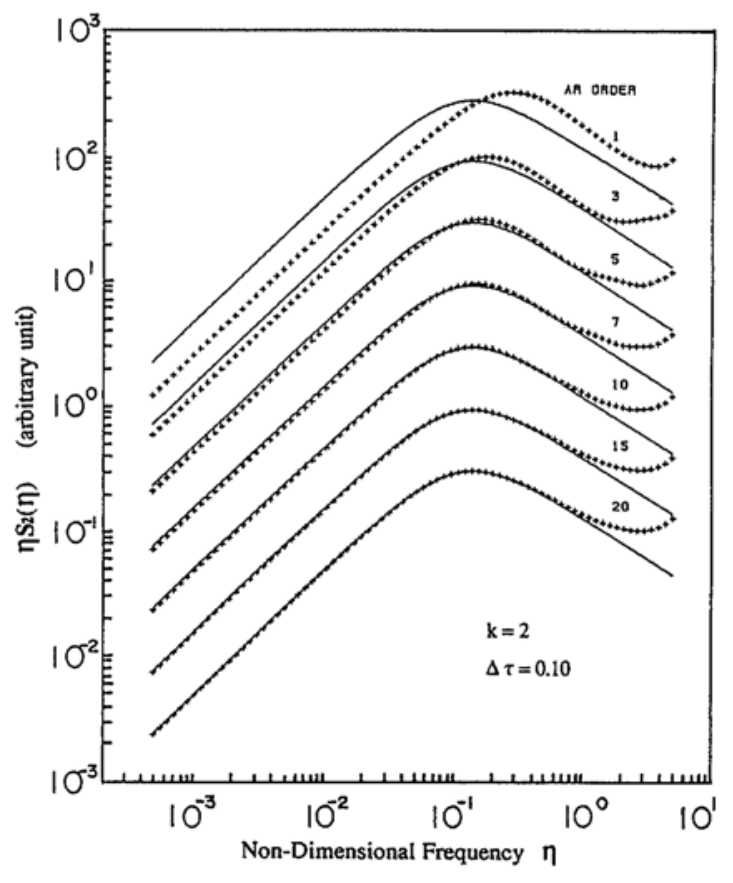

Fig. 6 The disagreements reproduced with the present method between model (solid line) and estimated (symbol +++ ) spectra in high frequency range, which are similar to the results shown by Maeda ${ }^{5)}$.

おける値とは明らかに異なり, 高周波側にずれている。 この結果は前田 ${ }^{5)}$ のFig. 5 の上から 3 段目のグラフの 次数 1 の結果とよく一致している。次数 5 と10の結果 についても前田のそれとよく一致している。筆者のこ の方法と前田の方法は必ずしも同一ではないが前田の 結果がほぼ再現できている。なお簕者の結果の方が高 周波の端での不一致が大きく見えるが，前田の図では 無次元周波数で 2 程度以上からナイキスト周波数 5 ま での值が描かれていないためである。このように前田 の方法では高周波の端の領域でのモデルとARスペク トルの比較が基本的にできない。

以上のように，両者の方法には一長一短があり，そ れを十分に把握して利用することが必要である。これ は風速変動のシミュレーションの際にも考慮しなけれ ばならないことであるとともに, 測定データから得た スペクトルの関数近似の際にも両者の対象周波数帯が 異なることを念頭に置かなければならないこととも関 係している。 


\section{9. 積分スケールについて}

ここで積分スケールのA R 次数による変化の様子を 見てみたい。前田 ${ }^{5)}$ によればカルマンタイプのスペク トルの場合で $\Delta \tau$ が0.1 のときには誤差 $5 \%$ あるいは $3 \%$ 推定できた最小のA R 次数はそれぞれ 8 と11で あった。筆者の方法では同じ条件ではそれぞれ 9 と 11 であった。ほぼ同じ値が得られた。同形のスペクトル の場合でも $\Delta \tau か ゙ 0.05 ， 0.02$ 場合には誤差を $5 \%$ 以 下にするには，16，32以上の次数が必要であり，3\% 以下にするには $21 ， 52$ 以上の次数を必要とする。モデ ルのスペクトルに対する積分スケールを基準にして， さまざまな次数の解析から得られる積分スケールの割 合をその次数の関数としてFig. 7 に示す。次数が 2 の 場合を除いて，次数の增大とともにその割合は大きく なり,やがて $1 に$ 近づく。 $\mathrm{k}=1$ の場合よりも $\mathrm{k}=2$ の場合の方がはるかに 1 への収束が速い。また時間間 隔 $\Delta \tau$ が大きくなるとともにその収束が速くなる。こ の図の中で収束の最も遅い $\mathrm{k}=1$ で $\Delta \tau=0.02$ の場合 には, 次数が500 でもその割合は 0.93 程度である。 $\mathrm{k}$ $=1$ で $\Delta \tau=0.10$ の場合には，算定誤差を $5 \%$ 以下に するには次数を 160 から 170 程度にする必要がある。

\section{0. むすび}

理論的な意味での戦密さはなく，また，数値計算上 においても非常に厳密な意味での正確さを求めない方 法によってではあるが，自己回㷌式を用いたスペクト ル解析法の問題点と限界などについて考察した。ここ で用いた方法ではF P Eについて直接的には議論がで きない。しかし，過去の経験などとも関連させながら, F P Eを用いる次数の決定法の問題にも触れた。筆者 がかつてMEMに関連して, 同様の問題について検討 を行なったが,この際にはシミュレートした変動を用 いたためにデータの長さと次数の関係について議論で きたが今回の方法ではもちろんそれもできない。 $\mathrm{ME}$ Mの場合に小さすぎる次数で解析したときに得られる スペクトルはもとのスペクトルに関係なくカルマンタ イプのものになると指摘したが, 今回検討したAR法 の場合にも全く同様のことが指摘できる。これは変動 をシミュレートする際とか, 相関係数を計算する際と かの誤差に起因するものではなく，AR法そのものの 性質に関わるものである。近年の大気乱流における風 のスペクトルの測定結果として， $5 / 3$ 以下の $\mathrm{k}$ の值を もつ式(1)において近似されるものが数多く発表され ているが，もし測定データがそのようなスペクトルを

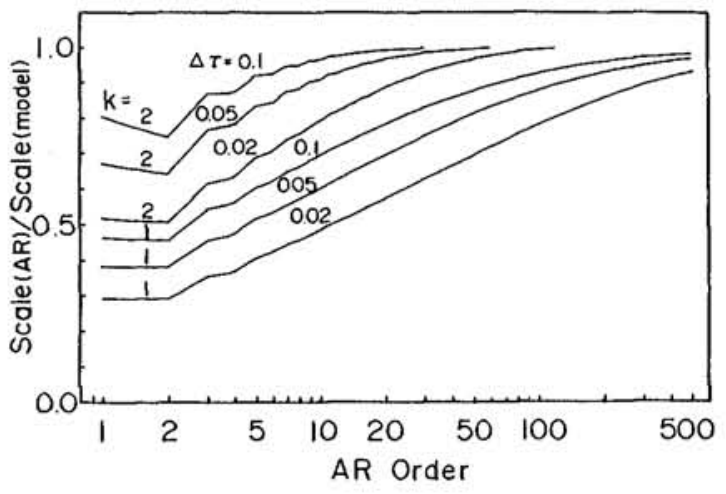

Fig. 7 The ratio of estimated scale to the scale obtained from eq. (6) expressed as a function of AR order.

もつ変動であってもF P Eで次数を決定して解析する と, 結果は本来のスペクトルに関係なく, $\mathrm{k}=2$ で表 わされるカルマンタイプの式で近似できるという結果 につながる可能性が極めて高い。測定データにあって はあらかじめスペクトルのタイプがわかっているわけ でないので，平坦な場所での大気乱流の風の変動など をF P E を基準にして解析することは避けなければな らない。次数を大きくすれば算定誤差が大きな相関係 数を使用することになるので賛成できないということ であるが，ある程度の次数の大きさは必須である。こ の場合の相関係数の算定誤差については系統的な傾向 は存在しないので, 多数の測定で事実に接近が可能で あるが, 低すぎる次数の解析では系統的な歪が存在す る。例えば, 式(1) の $\mathrm{k}=1$ の夕イプの変動であって も，そのようなタイプのスペクトルであるという結果 は低すぎる次数の解析からはいくら多数のデー夕を解 析して平均化しても得られない。式(1)において $\mathrm{k}=$ 1 の場合などに, それに応じて必要な大きさの次数が F P E を基準にして得られれば問題はないが，筆者の 経験等の範囲のことではあるが，そのようなことには ならなかった。もちろん $\Delta \tau$ をかなり大きくとればあ るいは可能かも知れないが（確認はしていない），特 別の可能な例を取り上げても仕方がないことである。 一般的な多くの場合に歪んだ結果をもたらす可能性の 高い方法の使用は避けるべきである。

では必要な大きさの次数はいったいいくらであるか という問題が残る。今回の検討結果では次数は大きい ほどよく，より大きな次数に対してより低周波領域ま で正確なスペクトルが得られるという当然の結果が得 
られた。当然とはいいながら,この結果は相関係数の 值が篇密に正確ではないとはいえ, 相応の精度で得ら れていることが前提となっている。実際のデー夕解析 の場合には，そのデー夕長によって次数の大きさに自 ずと限界があることも確かである。次数の大きさのお おまかな目安についてはシミュレートされたデー夕を 用いた検討結果をすでに報告”している。その際の検 討では, シミュレーションの誤差によるのか, 相関係 数の算定誤差によるかは明確ではないが，次数を大き くし過ざると得られるスペクトルの不安定さが増して きた。非定常性などさらにスペクトルがばらつく要素 をふくむ観測データでは，ある程度のスペクトルのば らつきは避けられないだろう。大局的にみて同一とみ られる条件下で多数のデー夕を収集解析してその結果 を平均化して滑らかなスペクトルを得ることこそが信 頼のできる結果を得るための正道であると考える。

最後に，正確なスペクトルが得られるような次数の 決定法についてのより一般的な方法が開発されること， あるいはこの問題をめぐって理論的な考察が哚められ ることに期待を表明して結びとしたい。

最後になったが文中で論文などを引用する際の著者 名等の敬称を省略したことをご容敖くださるようにお 願いする次第です。本文は論文ではないので敬称をつ けることが筋であるとの気持ちも強かったが, 研究上 の問題の討論に関する文章であるので, 科学論文の慣 例にここでも従わせていただいた。

\section{参考文献}

1）岩谷；MEMによるスペクトル解析について，日 本風工学会誌, Vol. $35,1988, \mathrm{pp} 45-47$.

2) 岩谷, 塩谷; 強風の乱れのパワースペクトルーM EMによる解析一, 日本気象学会1983年秋期大会講 演予稿集, 1983, p126.

3）岩谷; 広带域連続スペクトルをもつ変動のM EM による解析, 日本気象学会1984年春期大会講演子稿 集, 1984, p84.

4）日野; スペクトル解析, 朝含茟店, 1977, pp300.

5）前田；乱流スペクトルの自己回帰モデルへのあて はめについてー1 次元解析の場合一, 日本風工学会 誌, Vol. 42, 1990, pp43-48.

6) 前田, 牧野, 足立; 強風時変動風速の空間構造に 関する考察一台風7916号接近時の観測資料にもとづ いてー, 第 6 回風工学シンポジウム論文集, 1980 , pp17-24.

7）岩谷; 与えられたパワースペクトルとクロススペ クトルをもつ多次元風速変動のシミュレーションと その精度の検討, 日本風工学会誌, Vol . 36, 1988, pp11-26.

8) G.H. Fichtl and G. E. McVehil;Longitudinal and lateral spectra of turbulence in the atmospheric boundary layer at the Kennedy Space Center, J. Appl. Meteor., Vol. 9, 1970, pp51-63.

9) F. Pasquill and H.E. Butler; A note on determining the scale of turbulence, Quart. J. Roy. Meteor. Soc, , Vol. 90, 1964, pp79-84. 